Review

\title{
Assessment of Dust Event By RS, GIS, MODIS and Statistical Methods Among Satellite Images
}

\author{
${ }^{1,2}$ Kaveh Ostad-Ali-Askari, ${ }^{3}$ Naimeh Rahimi, ${ }^{4}$ Parisa Ashrafi, \\ ${ }^{5}$ Hossein Gholami, ${ }^{6}$ Amir-Hossein Ashrafi and ${ }^{6}$ Shahide Dehghan \\ 1,2Department of Water Engineering, College of Agriculture, Isfahan University of Technology, Isfahan, 8415683111, \\ Iran and Department of Civil Engineering, School of Engineering, American University in Dubai, Media City, Dubai, P. O. Box \\ 28282, United Arab Emirates \\ ${ }^{3}$ Department of Physical Geography, Faculty of Earth Sciences, Shahid Beheshti University, Tehran, 1983969411, Iran \\ ${ }^{4}$ Department of Architecture and Art, University of Kashan, Kashan, Iran \\ ${ }^{5}$ Department of Civil Engineering, Isfahan (Khorasgan) Branch, Islamic Azad University, Isfahan, Iran \\ ${ }^{6}$ Department of Geography, Najafabad Branch, Islamic Azad University, Najafabad, Iran
}

\author{
Article history \\ Received: 20-04-2018 \\ Revised: 16-05-2018 \\ Accepted: 28-05-2018 \\ Corresponding Author: \\ Kaveh Ostad-Ali-Askari \\ Department of Water \\ Engineering, College of \\ Agriculture, Isfahan University \\ of Technology, Isfahan, \\ 8415683111, Iran and \\ Department of Civil \\ Engineering, School of \\ Engineering, American \\ University in Dubai, Media \\ City, Dubai, P. O. Box28282, \\ United Arab Emirates \\ Email: ostadaliaskari.k@of.iut.ac.ir
}

\begin{abstract}
Dust is an event that occurs in most sections of the world that leads to financial loss and harmful environmental impacts. Several factors are included in dust event incidence, some of them are natural and others are due to human processes and their impact on the environment. Thus, very critical situations are coming and it is expected that the majority of urban and rural populations will migrate to the rest of the country, especially from western and southwestern regions leading the way to a lot of economic damage. Studies conducted in the country showed that the western regions of the country are more exposed to dust systems due to their geographical and climatic location and the proximity to the deserts of neighboring countries such as Iraq, Syria and Saudi Arabia, especially since most of the atmospheric system of the North West, West and Southwest are imported into the country. For this purpose, investigating, studying and recognizing physical and chemical composition of dust and soil resulting from it to determine and identify harmful elements and ultimately policy-making and planning for its elimination as regional alliances in the field of policy-making and foreign co-operation vital. According to the obtained results, it was found that the dust in spring of 2015 in Zahedan city has spatial and temporal changes. The spatial and temporal changes in dust can be caused due to the low green space, especially in the direction of wind blowing, developmental activities and 120-day winds of Sistan and the difference in urban density and urban marginal topographic complications. According to zoning map in the spring of 2015, the existence of an inconsistency in the dust spatial variations in the spring indicated that spring is the source of dust in the city. Since part of this amount is due to the drying of Hamoon Lake, wind erosion control measures in these areas can be effective in reducing the loss of dust in the city of Zahedan. In Iran, the use of geographical information systems and remote sensing to monitor natural hazards is increasing. Hence, the attention of managers of various fields of natural resources and environment to the capabilities of this software and attention to the researches have done in this regard sound necessary and useful. The results of many studies in the country showed that the frequency of dusty days is increasing.
\end{abstract}

Keywords: Dust, Heavy Metals, Remote Sensing, Geographical Information System, Statistical Methods

\section{Introduction}

Dust is recognized as one of the atmospheric phenomena and natural disasters, which has adverse effects on the environment. Dust may influence the temperature due to the absorption or diffusion of solar beams or may change the shape of the clouds (Goudie, 2009). Falling dust is a dust that falls from the atmosphere 
on the surface of the earth and we can indirectly examine the contamination of the entire suspended particles through studying the falling dust (Nimrozi and Moafpourian, 2012). The term "dust" refers to aerosols with a diameter of 12 microns or more, which can be deposited after the temporary suspension (Chung et al., 2003). The dust cycle is an important part of the planet Earth system. Annually 2000 tons of dust are released, of which $75 \%$ is deposited on the soil and $25 \%$ on the ocean, this process affects the energy, water and carbon cycle (Rodríguez et al., 2009). The highest amount of dust in the atmosphere occurs with the origin of fine-grained particles, which are more prevalent in arid and semi-arid regions. In recent years, seemingly, changes in the frequency of this risky climatic phenomenon occurrence have led to problems in some parts of our country (Hamzeh et al., 2009). In fact, the dust formation can be a reaction to the change in land cover, in which the role of human activities along with the natural environment of the geographic environment should be taken into consideration. Humans can also modulate the negative effects of dust storms through some large-scale engineering plans (Nadafi, 2009). The phenomenon of fine dust particles has been increasingly evident in the world system in recent years and the occurrence of dust storms caused environmental effects such as air temperature (Ridgwell, 2003), a significant increase in the melting of icebergs (Krinner et al., 2006), changes in the formation and evolution of soils (Yang et al., 2008) and damage in agricultural sector. The amount of dust particles' effect can be investigated according to their physical and chemical characteristics so that investigating the mineralogical properties and the size of the sedimentary particle, the erosion origin and distance that particle traveled can be realized (Frechen and Dodonov, 1998). More than two third of our country is located in desert and semi-desert climate due to its geographical location. One of the most significant events in these areas is wind erosion, which indicates the potential of nature to move soil particles (Toy et al., 2002). Most of the dust sources are in the Middle East and Southwest Asia, the Arabian Peninsula and the surrounding deserts, which are most active from April to July (Gossens and Rajort, 2008). Iran has encountered numerous dust storms in recent years (Prospero et al., 2002). Studies that have been carried out germane to the abundance of dusty days in the country showed that the central pits of Iran have the highest number of dusty days. Dust particles are considered as a great risk for human health because of the potentially toxic effects that various heavy metals have in these particles (dust containing mercury, arsenic and cadmium) (Holden, 2006). Pollutants are among the environmental disruptors (Wu et al., 2011). Heavy metals are among the environmental pollutants. The correct estimation of dust amount on the surface of the earth is essential in many fields, including water and soil contamination caused by toxic and polluted particles (Sow et al., 2006). Heavy metals are classified into the most hazardous group of human pollutants due to their toxicity and persistence in the environment (Sharma et al., 2008). Determining the number of metals in environmental samples such as dust, plants, soil and surface waters is greatly essential in monitoring environmental pollutants (Al-Khashman, 2007). The natural concentration of the elements in soils varies widely. The evaluation of dust pollution to heavy metals is one of the fundamental tasks for controlling and managing the dust phenomenon, although the natural concentration of heavy metals in soils are studied in many countries including Poland and many other European countries, the United States and China (Azimzadeh and Khademi, 2013; Su and Yang, 2008). This evaluation is based on the use of various indices such as geostationary index, normal enrichment factor, degree of contamination, pollution factor and pollution index (Loska et al., 2004). The present study is a structured review study aimed at monitoring and evaluating dust using remote sensing data, geographic information systems, satellite imagery, as well as sampling during spring of 2015 in Zahedan, in order to compare the results with the results of the previous and survey of spatial and temporal distribution of dust in the city of Zahedan. Shayestefar and Rezaei (2011) evaluated the amount of heavy metals' contamination in Sarcheshmeh copper deposits. In this study, the Contamination Factor (CF), Pollution Load Index (PLI), Enrichment Factors (EF) and geo-accumulation index (Igeo) were based on the following formula:

$C F=C_{\text {sample }} / C_{\text {background }}$

where, $C F$ is the contaminant factor, $C_{\text {sample }}$ is the concentration of metal in the sample and the $C_{\text {background }}$ is the concentration of metal in the sample field. If $C F>1$, it indicates the presence of contamination and, if $C F<1$, it means no metal contamination:

$$
P L I=\sqrt[n]{C F_{1} \times C F_{2} \times C F_{3} \times \ldots \times C F P I_{n}}
$$

The index is closer to the number one heavy metal concentrations near background levels and if it is greater than 1, the soil is contaminated (Adomako et al., 2008; Qishlaqi et al., 2009):

$$
E F=[C x / \text { Cref }] \text { sample } /[C x / \text { Cref }] \text { background }
$$

where, $E F$ is the enrichment factor, $C x$ is the concentration of the element studied, Cref is the concentration of the reference element in the shell:

$$
\text { Igeo }=\log 2\left(\left(C_{n}\right) / \times 1 / 5 B_{n}\right)
$$

where, $C_{n}$ is the concentration of the element studied in soil sample or sediment (mist), $B_{n}$ is the concentration of the element studied in the field value (mean global shale) and the coefficient 1.5 to eliminate the lithology's effect (Muller, 1969). The results indicate that $\mathrm{Cu}, \mathrm{Mo}, \mathrm{Zn}, \mathrm{Mn}, \mathrm{Pb}$ 
and Fe metals have been enriched in sediment samples. According to the values of the geoaccumulation index, the sediment accumulation in the region has been heavily contaminated with $\mathrm{Cu}, \mathrm{Zn}$ and Fe metals. The contamination coefficient for $\mathrm{Cu}, \mathrm{Mo}, \mathrm{Zn}, \mathrm{Mn}, \mathrm{Pb}$ and Fe metals is more than 1, which indicates the high concentration of these metals and the impact of human and natural factors on the concentration of these metals.

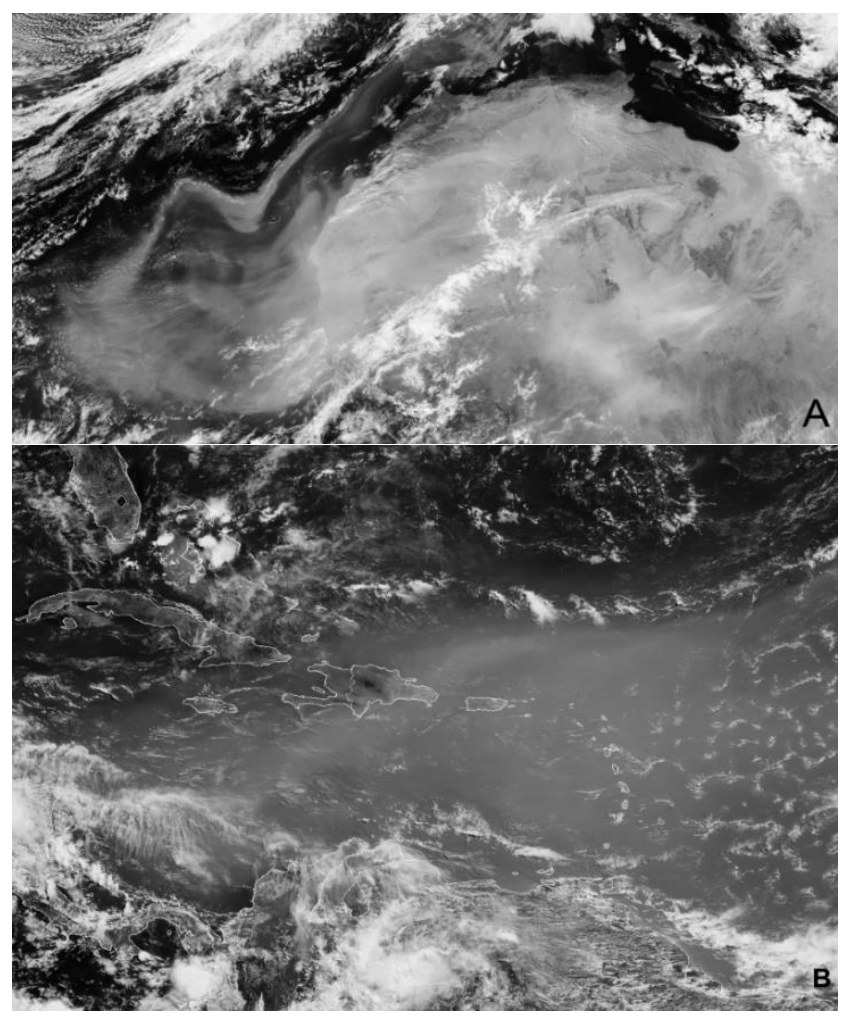

Fig. 1: True-color image of dust (A) and image enhancement (B) 2012 June 18

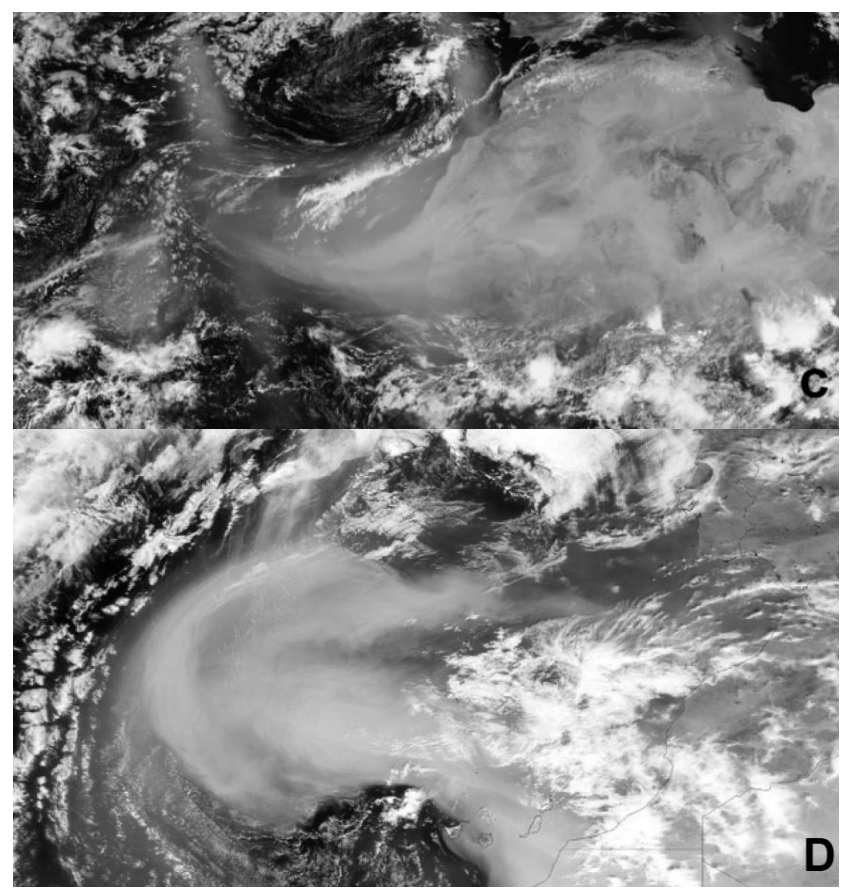

Fig. 2: True-color image of dust (C) and image enhancement (D) 2012 June 19 


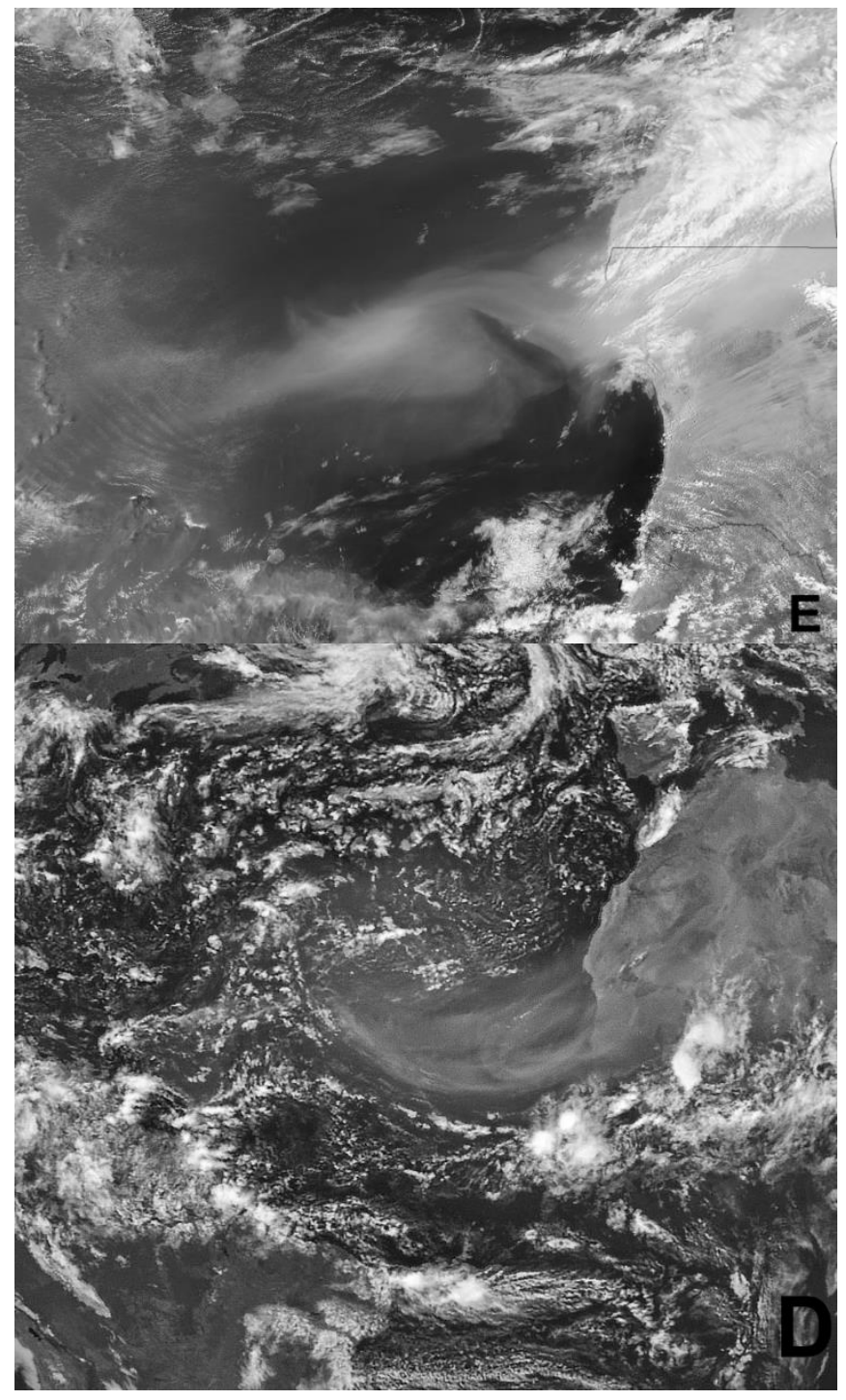

Fig. 3: True-color image of dust (E) and image enhancement (F) 2012 June 20

The spatial analysis of this phenomenon indicates that the main areas of dust activity are deserts, including sand deserts that have been destroyed by humans (Indoitu et al., 2012). The investigations showed that, according to the purpose, different materials and methods are used such as remote sensing data and related software in this field to highlight the dust phenomenon and the use of synoptic data in the analysis of the emergence of this phenomenon on the surface of the earth, as well as its transportation to the atmosphere and modeling their movement and displaying it in the GIS environment and other cases which will be referred to in other part of this study. In a study (FallahZozooly et al., 2014) using the MODIS satellite imagery to monitor and evaluate the dust storm on June 18, 2012, in West and South-West Iran. The results showed that the main source of dust junction of the Tigris and Euphrates rivers, respectively. "Figure 1A" shows that this storm has started from the eastern border of Syria and the western border of Iraq, which is clear in the picture. "Figure $1 \mathrm{~B}$ " is an acronym detection image, in which the black and pink areas show the amount of dust that darkens the dust and increases in the central part and near the eastern border of Syria and southern Iraq and northern Arabia. Furthermore, this dust is entering Iran and is observed in the provinces of Khuzestan, Ilam, Kermanshah and southeast of Iraq "Fig. 2C". In image enhancement by the 19 June 2012 "Fig. 2D" shows a dust density that is pink to black in color, indicating a high density in black. In" Fig. 3E" which relates to June 20 , the dust entering Iran is due to lack of sufficient wind in the same provinces. In "Fig. 3F" a detected image of black density is observed in Khuzestan and Ilam provinces. Also, in pictures of June 21, dust completely entered Iran and is far from the southwest boundary and is entering the Persian Gulf "Fig. 4G and 4H". 


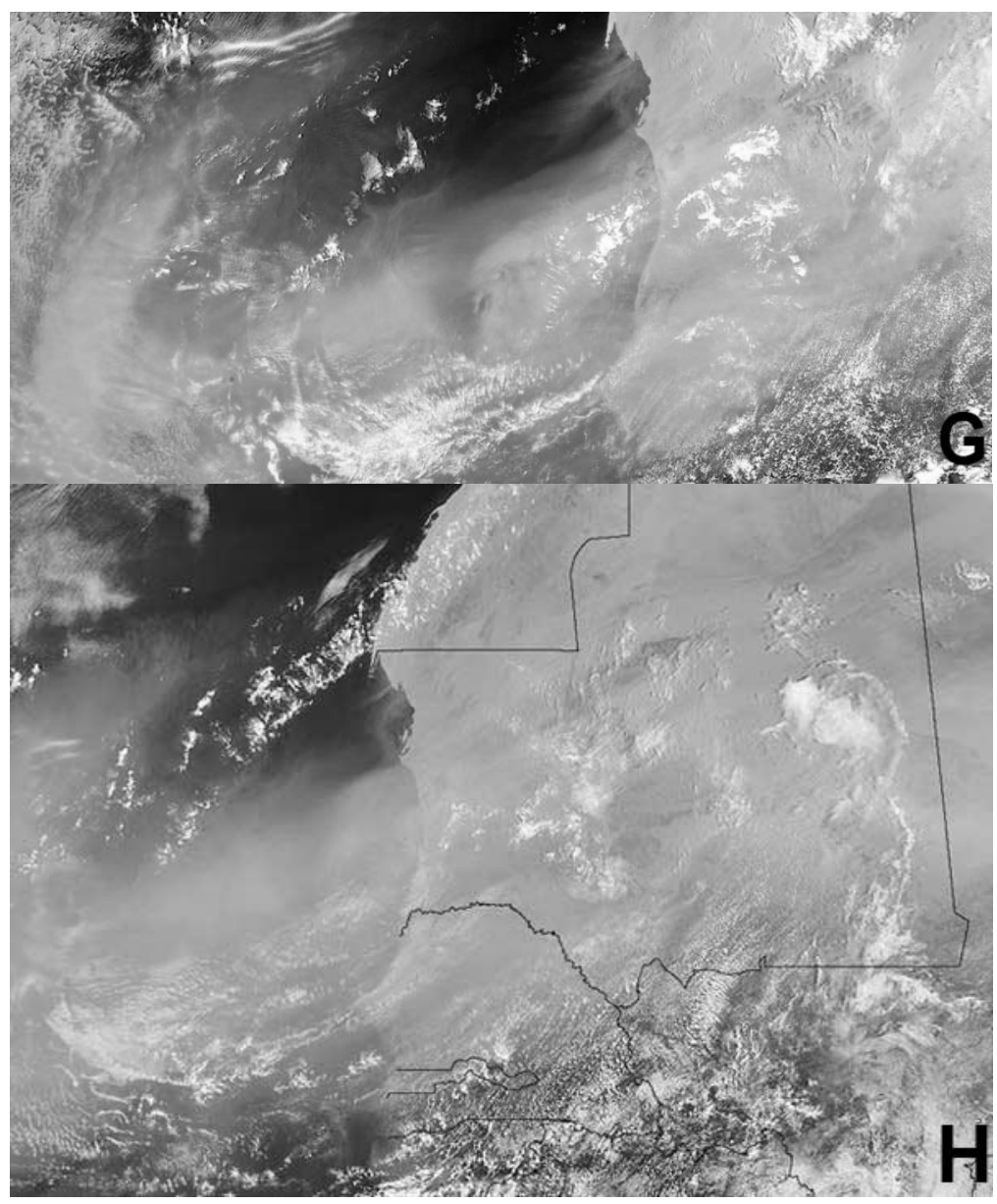

Fig. 4: True-color image of dust (G) and image enhancement (H) 2012 June 21

\section{Fundamentals and Theoretical Framework}

Firstly, definitions related to the dust topic will be given that are frequently mentioned in various articles.

\section{Remote Sensing}

Remote sensing Science is the technology and art of obtaining information about distant phenomena, in other words, collecting information from areas that are not directly accessible due to danger, high cost and distance (Darvish-Sefat et al., 2013).

\section{Geographical Information System}

This system allows you to save up-to-date information about Earth and to combine them with other information. This knowledge is applicable in various fields such as urban and regional planning, or environmental planning, geology and mining studies, agriculture and natural resources and etc.

\section{Fine Dust Particles}

A fine dust particles'storm is a complicated process that is affected by the interaction of the atmosphere-Earth system and often resulting from high wind speed, dry soil and dry climatic conditions (Mei et al., 2008).

\section{Heavy Elements}

Heavy elements are among those materials that have a higher atomic mass than iron and are highly absorbed into living tissues, accumulate in them and exhausting them from the tissue happens hardly such as zinc, cadmium, cobalt, copper, lead, nickel, arsenic, vanadium, chromium (Rossini et al., 2010).

\section{Dust Falling}

Dust falling defines as dust that falls from the atmosphere on the surface of the earth, studying which can lead the way to indirectly investigating all of the suspended particles' contamination (Hai et al., 2008).

Most studies done on dust phenomena have mostly addressed the statistical and storm origin investigations and less on the relationship between dust storms and the factors affecting their occurrence. Hence, investigating the researchers carried out in relation to dust storms, a comprehensive review of the occurrence of this destructive environmental phenomenon is indicated 
(Tamsaki et al., 2016). According to the purpose of the study, various materials and methods such as the use of remote sensing data and software germane to this field in dust falling phenomena and the use of synoptic data in analyzing how this phenomenon happened on the surface of the earth, as well as carrying it in the atmosphere and modeling its movement and displaying it in the GIS environment (Fallah-Zozooly et al., 2014), which will be referred to in following parts of this study.

\section{Methodology}

This study is a collection of basic studies of dust phenomenon in the country. This paper has been dedicated to the evaluation of data and statistical analysis in the present time period after an initial examination and review of past generality and studies. Finally, efforts have been made to analyze the dust phenomenon according to the statistics obtained in different parts of the country. This research was conducted through structured review with the aim of monitoring and investigating the dust phenomenon in Iran. For this purpose, the SID, Google Scholar, Magiran and Iranmedex databases were searched for collecting local articles and the Science direct database was searched for English articles between 1992 and 2016. The English keywords include Dust fall, Heavy metal analysis, Soil contamination and remote sensing and Persian keywords including Dust, heavy metals, remote sensing and geographical information systems. The criteria for entering this study are research articles that use statistical methods, remote sensing and GIS in the source finding field and spatial distribution of dust. Then available full-text articles were taken into consideration. Required data including the introduction of the article, the location of the study, the purpose of the study, the sources of data collection and the area under study were extracted. Most of the articles collected their required data through dust sampling and some used MODIS images, TOMS and OMI images, AVHRR images, METEOSAT images and Sea-WIFS images to reveal and monitor dust storms. Mentioning differences of this study with previous studies, it can be noted that in this study, in addition to studying and analyzing previous studies, a dust sampling period and dust monitoring in Zahedan City in the spring of 2015 have been done. The random sampling method was used to determine the sampling points. Thus, 30 stations were selected in the city. Mildew Trap (MDCO) was used to investigate the loss of dust. The sampler was placed at a height of 1.5 meters from the roof. The sampling of mist was carried out during the spring of 2015. Overall, 90 dust samples were taken from 30 stations in the city. At the same time as each sample was taken, the geographic coordinates of each point were recorded using GPS in the UTM system. During this 6 month period, trapped mist in sediment traps was carefully collected on a monthly basis and weighed accurately using a scale of $0.001 \mathrm{~g}$. One-way ANOVA was used to study the variation of dust in different sampling locations in the spring season. To investigate the spatial variability of dust, the geostatistical method was used. After the information file was prepared, the input file of Arc GIS 9.3 software was prepared. Finally, the distribution of dust in the city zoning map was obtained.

\section{Findings}

Structurally researching keywords in online databases, 102 articles were retrieved. After removing 12 duplicate articles, 90 eligible articles were selected for further analysis. The results indicated that the number of articles in the investigation and source finding of dust has increased over time. Various sources were used to collect data. The studied articles were classified into three categories including the concentration of heavy elements in dust and spatial distribution zoning of dust and dust detection. Statistical studies of dust phenomenon for the purpose of time analysis showed that the number of days of this phenomenon occurs is increasing and happening most frequently in June and July and among these studies, only one of them has shown a decreasing trend. (Mehrshahi and Nekounam, 2009; Omidvar and Nekounam, 2009; Zarasvandi et al., 2011). The spatial analysis of this phenomenon indicated that the main areas of dust field activities are deserts, including sand dunes which have been destroyed by humans (Indoitu et al., 2012). The results of One-way ANOVA obtained from sampling and analysis of dust data in Zahedan city, which was studied in this article along with previous studies, indicated that the variance between months and stations in spring is not significant, "Table 1 and 2". Geoaccumulation were used to zone the distribution of scattering dust in Zahedan. After analyzing and normalizing the data, the Kriging method was finally used for zoning. The study of the zoning map of falling dust in spring showed that the amount of the falling dust at the stations of Moallem, Hirmand and Mir-Hosseini is more than other stations and the falling dust measured at Mazar 2, Farrokhi-Sistani and Ashrafi-Esfahani stations are less than others "Fig. 5".

Table 1: The results of the variance analysis test of falling dust between the months and places in spring 2015

\begin{tabular}{lllll} 
& Time & & & \\
Change sources & df & Sum of squares & Mean squares & F \\
\hline Month & 2 & 1.706 & 0.853 & 1.384 \\
Error & 78 & 53.635 & 0.616 & \\
Total & 89 & 55.341 & & \\
\hline
\end{tabular}

ns: No significant difference 
Kaveh Ostad-Ali-Askari et al. / American Journal of Engineering and Applied Sciences 2021, 14 (2): 198.213 DOI: 10.3844/ajeassp.2021.198.213

Table 2: The results of the analysis of the variance of lavatory dust between different locations in spring 2015

\begin{tabular}{lllll}
\hline & Place & & & \\
Sources change & df & Sum of squares & Mean squares & F \\
\hline Month & 29 & 16.661 & 0.575 & 0.891 \\
Error & 60 & 38.680 & 0.645 & \\
Total & 89 & 55.341 & & ${ }^{n} 0.62$ \\
\hline
\end{tabular}

ns: No significant difference

Table 3: The frequency of dusty days in the statistical period of 1988- 2008

\begin{tabular}{lrrrrr}
\hline Year & 1989 & 1990 & 1991 & 1992 & \\
\hline Frequency & 16 & 29 & 15 & 8 & 1993 \\
Year & 1994 & 1995 & 1996 & 9 & 1997 \\
Frequency & 14 & 13 & 2001 & 19 & 1998 \\
Year & 1999 & 12000 & 21 & 2002 & 10 \\
Frequency & 2 & 2005 & 2006 & 17 & 2003 \\
Year & 2004 & 19 & 23 & 19 & 16 \\
Frequency & 27 & & & 49 \\
\hline
\end{tabular}

Table 4: Subsidence rate of atmospheric dust in seasons (gr.m ${ }^{2} *$ day)

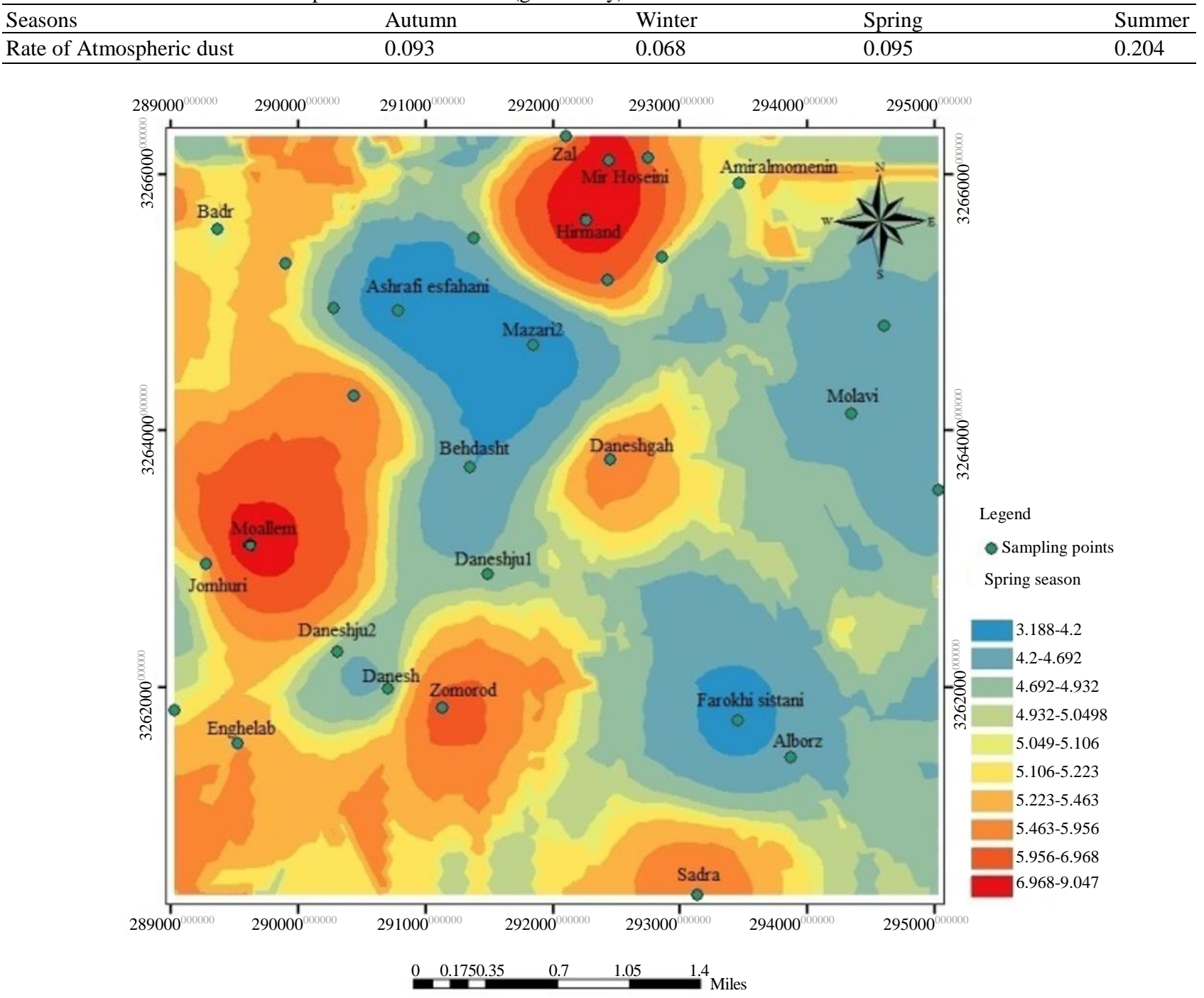

Fig. 5: Landing dust mapping schedule of spring 2015 
In a study by Mehrshahi and Nekounam (2009), the spatial and temporal aspects of dust in a 20 -year period from 1988 to 2008 in Sabzevar city were investigated. The statistical results of this study showed that during the study period, the number of days with dust had an increasing trend and the most likely occurrence was in May and June. "Table 3" showed the frequency of days with dust and graph 1showed the frequency percent and the annual trend of dusty days in the studied period. According to the statistics, 2008 with 49 days and 1999 with 2 have the highest and lowest frequency of dusty days, respectively. It reveals the fact that with all efforts done to control and promote this phenomenon by the Natural Resources Department, the number of dusty days has increased in this period.

Namazi et al. (2015) conducted another study to investigate the spatial and temporal variations of heavy metals in atmospheric dust in the Lenjanat region of Isfahan. Sampling was done in 60 regions with almost identical height in the areas using glass traps during the four seasons of the year and the total dust content and the number of heavy metals, cadmium, lead, zinc, copper and nickel were measured. To determine the weight of dust in the area and period of time, dust subsidence rate was calculated by the following formula:

$$
\begin{aligned}
& \text { Atmospheric Deterioration Rate }\left(\text { gr. } \mathrm{m}^{2} * \text { day }\right) \\
& =\text { Dust Mass }(\mathrm{gr}) / \text { Trap Area }\left(\mathrm{m}^{2}\right) * \text { Sampling Period }(\text { day })
\end{aligned}
$$

The results demonstrated that the average amount of dust subsidence has a very significant difference in the level of \%99 in all seasons except spring and autumn "Table 4". The average concentrations of the elements studied in the majority of seasons were significantly different. The average concentrations of lead and cadmium in all seasons and zinc element except spring were higher than the reported limit for soil. There was a significant correlation between the concentration of some elements that could indicate their common origin "Table 5".The interpretation of Kriging maps showed that the pollution of the area to zinc, lead and cadmium was more under the control of the lead and zinc mine in the region. The level of consistency indicated a significant difference in the maps of each element in various seasons which was related to various factors such as wind speed and its direction, the amount and type of mine and industry activities and the amount of soil and air moisture.

One of the articles on determining the concentration of heavy elements in dust was a study by (Feng et al., 2008) who studied the dust in Jinan city in northern China. The samples were analyzed to study the amount of copper, lead, zinc and cadmium. The results showed that all four elements had a significant accumulation in the dust particles of this city and their concentrations were more than the basic limits. Yahaya et al. (2010) used composite sampling method in wet and dry season from the surface soil of intersections and highways in the city of Uyar to determine the concentration of as, $\mathrm{Cd}, \mathrm{Cr}, \mathrm{Cu}, \mathrm{Fe}, \mathrm{Ni}, \mathrm{Pb}$ and $\mathrm{Zn}$ in the obtained samples. The results showed that there is a high correlation between the studied metals except for nickel. Likewise, the concentration of metals in the dry season was higher than that in the wet season, "Table 6". Figure 6 Shows Regularity proportion and yearly tendency of rate of dirty times in Sabzevar city throughout the arithmetical time of 1988-2008. First, in 1990, Frequency Percentage has a miximum trend then the trend is decreased until suddendly It rises dramatically.

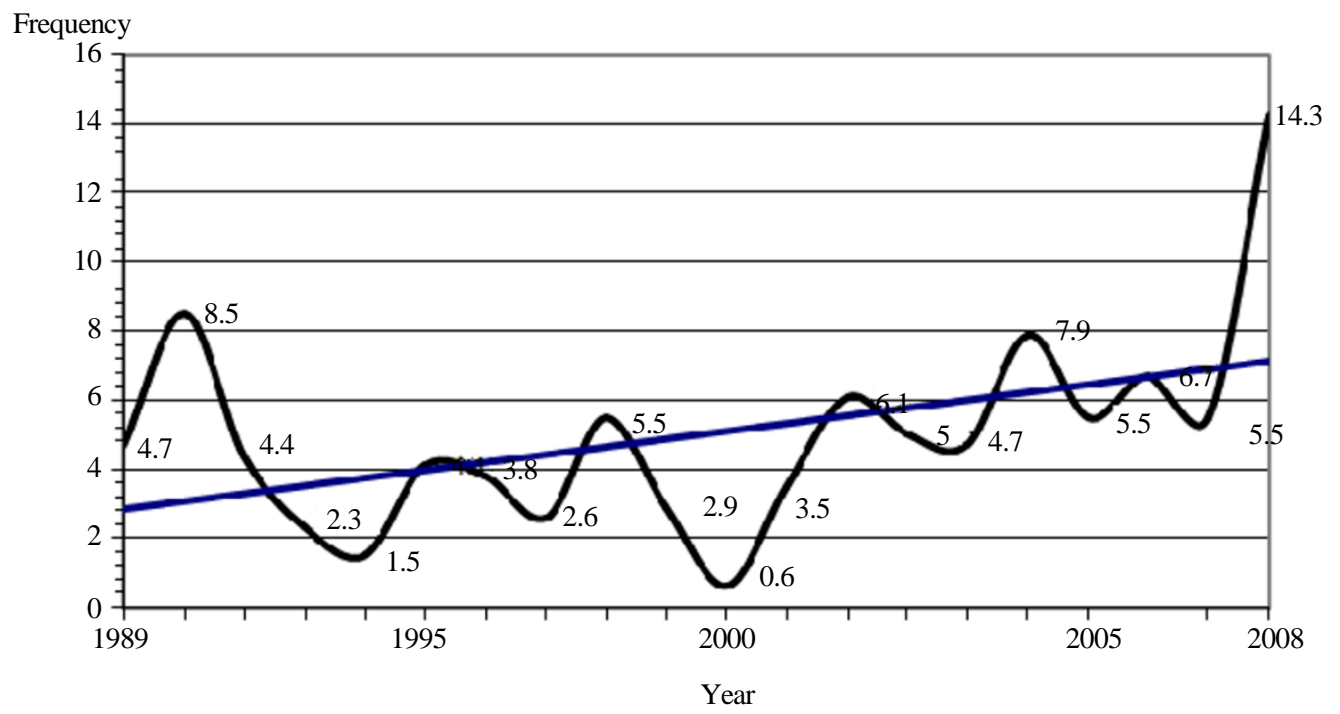

Fig. 6.Frequency percentage and annual trend of occurrence of dusty days in Sabzevar city during the statistical period of 1988 2008 
Kaveh Ostad-Ali-Askari et al. / American Journal of Engineering and Applied Sciences 2021, 14 (2): 198.213 DOI: 10.3844/ajeassp.2021.198.213

Table 5: Average element concentrations (mg.kg) at four seasons

\begin{tabular}{llllll}
\hline & $\mathrm{Zn}$ & $\mathrm{Pb}$ & $\mathrm{Cd}$ & $\mathrm{Cu}$ & $\mathrm{Ni}$ \\
\hline Autumn & $785.45 \mathrm{~b}$ & $256.83 \mathrm{ac}$ & $3.28 \mathrm{a}$ & $33.12 \mathrm{a}$ & $37.49 \mathrm{a}$ \\
Winter & $573.79 \mathrm{a}$ & $160.85 \mathrm{a}$ & $2.74 \mathrm{a}$ & $33.61 \mathrm{a}$ & $26.09 \mathrm{~b}$ \\
Spring & $279.31 \mathrm{c}$ & $133.81 \mathrm{~b}$ & $1.35 \mathrm{~b}$ & $14.43 \mathrm{~b}$ & $24.16 \mathrm{~b}$ \\
Summer & $596.95 \mathrm{a}$ & $524.31 \mathrm{c}$ & $6.13 \mathrm{c}$ & $22.32 \mathrm{c}$ & $48.26 \mathrm{c}$ \\
\hline
\end{tabular}

Table 6: Correlation of metals between wet and dry seasons

\begin{tabular}{lllllllll}
\hline Element & $\mathrm{As}$ & $\mathrm{Cd}$ & $\mathrm{Cr}$ & $\mathrm{Cu}$ & $\mathrm{Fe}$ & $\mathrm{Ni}$ & $\mathrm{Pb}$ & $\mathrm{Zn}$ \\
\hline Correlation & 0.71 & 0.46 & 0.86 & 0.75 & 0.56 & 0.23 & 0.87 & 0.66 \\
\hline $\mathrm{p}<0.05$ leve & & & & & &
\end{tabular}

Other studies that investigated the heavy elements found in dust are the studies of (Acosta et al., 2011; Bini et al., 2011; Cai et al., 2012; Chabukdhara and Nema, 2012; Chen et al., 2009; Eze et al., 2010; Gu et al., 2012; Lin et al., 2010; Lu et al., 2010; Micó et al., 2006; Reilly, 2008; Chaoyang et al., 2009; Xia et al., 2011; Zhang et al., 2008) that in all of them, the adverse effects of heavy metals on humans and the environment were highlighted as a big disaster. Among researches that used statistical geology methods and geographical information systems for extraction and analysis of information about heavy elements, the study of (Cai et al., 2012; Chabukdhara and Nema, 2012; Davis et al., 2009; Eze et al., 2010; Guo et al., 2012; Li and Feng, 2012; Lu et al., 2012; Qishlaqi et al., 2009; Xia et al., 2011; Yang et al., 2011) can be pointed out in which the distribution zoning of heavy metals in dust was discussed. In dust detection studies, Miller (2003) developed a methodology that is used to visualize the amount of dust on the surface of water and land during the day. He used MODIS sensor data for this purpose. Roskovensky and Liou (2005) used a four-band spectrum in order to distinguish the dust from Cyrus cloud. They used bands 4, 16, 31 and 32 in this method and concluded that values greater than 1 represent dust in this method. In other research, researchers such as (Rasouli et al., 2010; Zolfaghari and Abedzadeh, 2005) have investigated the spatial and temporal analysis of storms. Most of them resulted in an inclination in storms in recent years, especially in western part of Iran. Dusting phenomenon identification and identification of their origin areas using satellite imagery and using wind tunnel by (Ekhtesasi et al., 2006; Iranmanesh et al., 2005; Khosravi, 2010; Schlesinger et al., 2006) were considered as noteworthy. These studies also suggested that the main sources of dust entering the western part of Iran are usually Syria Desert, Iraq and the Arabian Desert, while the role of the great African Desert is considered insignificant. Kimura et al. (2009), investigating the relationship between the occurrence of dust storms, vegetation and soil moisture, pinpointed that dust storms occur when the normalized vegetation index is less than 0.2 , the wind speed is greater than or equal to $7 \mathrm{~m}$. s. and surface soil moisture is less than 0.2 and for normalized vegetation, greater than 0.2 , the wind speed must be greater than or equal to $9 \mathrm{~m}$. s. and the soil surface moisture must be less than 0.2. Shamsipour and Safarrad (2012) investigated the spatial and temporal changes of dust phenomenon in southwest of Iran. In this study, two maximum dust periods with different characteristics were identified. Lashkari and Keykhosravi (2008) analyzed the statistical analysis of dust storms in Khorasan Razavi province between 1993 and 2005 and determined that dust storms in the south of Khorasan Razavi province are a prevalent phenomenon, increasing from the north to the south. According to studies conducted by (Mei et al., 2008), it was concluded that the dust reflection value in band 32 is higher than the MODIS band of 31 and the difference between the brightness values between bands 31 and 32 is negative. Likewise, the value of Normalized Dispersion of Dust Index (NDDI) is a positive value. Li et al. (2010) evaluated the largest Australian dust with MODIS satellite images and the light temperature difference index and considering its remarkable efficiency in detecting dust masses, the way this phenomenon occurs has been identified. Tabatabaie et al. (2013) investigated the suspended particles' average of ten stations in three dust periods in Bushehr city to analyze the spatial variations of heavy metals concentrations of arsenic, cadmium, cobalt, iron, nickel, lead and vanadium. Geomagnetic Engineering, Geographical Information System (GIS) and discrete Kirijing method were used to prepare the spatial distribution map of seven metal concentrations. Also, Principal Components Analysis (PCA) and Correlation Matrix (CM) were used for data processing. The results of the segmental effect $\left(C_{0}\right)$ on the variogram threshold $\left(C_{0}+C\right)$ showed that the distribution of spatial variations of the seven elements is located in the middle average dependency class (0.25-0.75). This means that the entry of these metals into the studied area has an external origin. It should also be mentioned that, the 
Krjing method was used to quantify the concentration of metals. The analysis of the main component of seven heavy metals can be categorized in three components. In the first component, vanadium, cobalt, nickel and lead, in the second component of cadmium and the third component of iron showed the highest correlation. The result of this analysis showed that the origin of the concentration of these elements is an external factor. These results will help the environmental management of the region. In a research, NDDI index and temperature threshold of $290^{\circ} \mathrm{K}$ in the band of 32 were used for revealing dust fine particles. NDDI one of the best known indices in remote sensing to study dust "Formula 6":

$$
N D D I=b 7-b 3 / b 7+b 3
$$

where, $b 3$ and $b 7$ bands 3 and 7 sensors are MODIS. Then, the composition of the difference in the temperature of the brightness of the dust in the bands 32-31-29 (wavelengths of 8.5, 11, 12 micrometers) was measured by MODIS with negative values of the luminance difference of 31 and 32 bands, clear images of dust concentration were obtained. In this vein, during the warm seasons, especially in July, there has been a noticeable increase in dust and since 2007 it has an increasing trend. In this regard, December was the lowest due to the average rainfall and temperature decrease. During these years, the frequency of these storms in this province has not followed a certain pattern and order. The average concentration of particles in dusty days in Ahwaz compared to the standard concentration of particles in Iran is $11 \pm 16.5$ times (Negin et al., 2013). In other studies, researchers such as (Rivera et al., 2006; Tsolmon et al., 2008; Zoljoodi et al., 2013; Ataie and Ahmadi, 2010), Shamsipour and Safarrad (2012) and other scholars using remote sensing methods and using AVHRR imagery, NOAA satellite data, MODIS sensor data, meteorological data, orbital component data, halfwidth, lines of pressure, lines of altitude and etc tried to reveal and monitor the fine particles in different parts of the world and in Iran.

In some of these studies, natural resources were recognized as the factor of causing dust. In the Middle East, regions such as the west of Baghdad and Mosul to Bahrellmullah and Horealam, the northern coasts of the Euphrates River in Syria and the desert areas of Iraq are known as dust production centers. Rezaie-Moghaddam and Mahdian-Broujeni (2015) used the AVHRR imagery of NOAA satellites to identify the fine particles in the southwestern part of Iran (Fig. 6). In this regard, getting advantages of meteorological data and using popular algorithms for detecting the fine particles, they initiate recognizing and revealing fine particles. The images were extracted from 62 sources in the southwest of the country and 3 areas of western Ilam and its border with Iraq, which has the highest number of values in terms of density, northern of Khuzestan and Iraq and areas around the Hourolazim wetland were introduced as regions with frequent production of fine particles "Fig. 7".

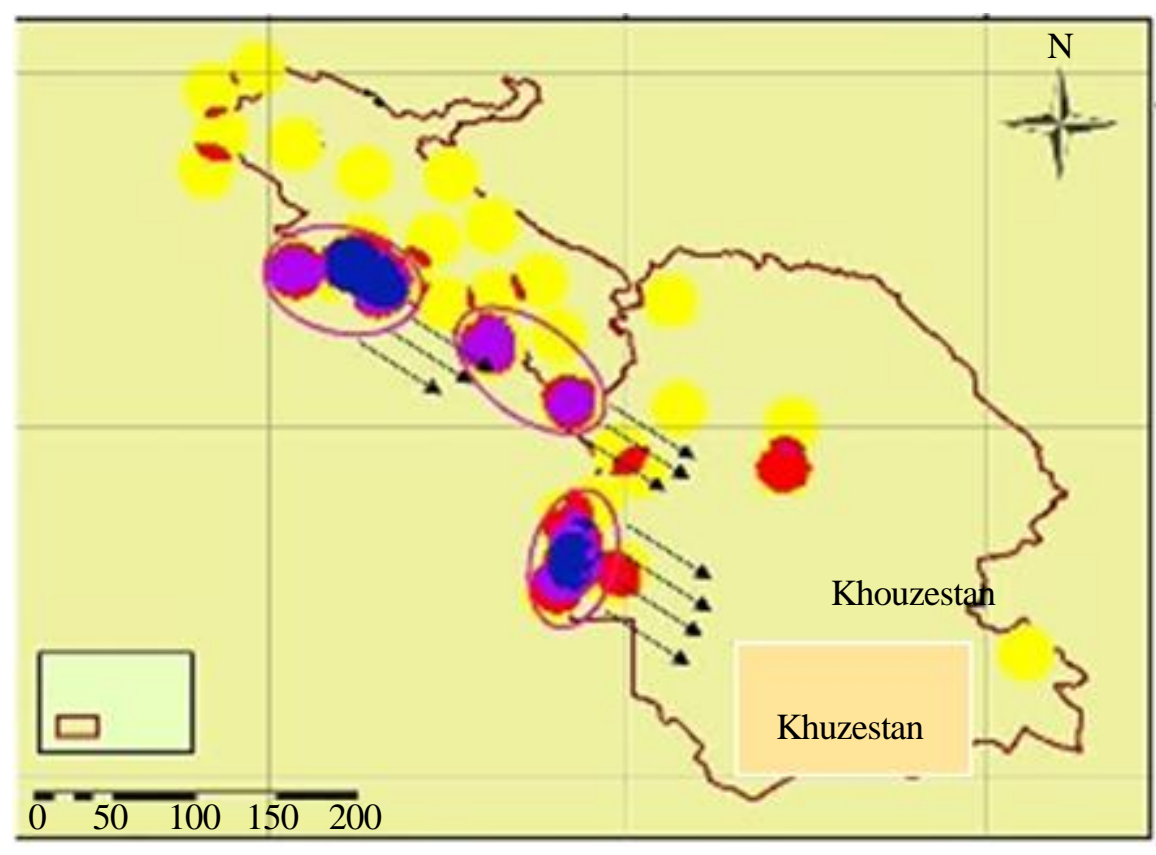

Fig. 7: Districts of the Fountains in the Southwest of the country 


\section{Discussion}

A prospective review study was conducted to investigate studies on dust recognition and dust monitoring. A review of various studies showed that this field of study was both qualitative and quantitative. A high percentage of studies have used remote sensing capability and geographical information system to investigate and detect dust. Numerous articles have been satisfied with the information provided by meteorological stations. Another category of studies was to study and to provide the zoning map of spatial distribution of dust in the study area (Azimzadeh et al., 2010) and another group of studies tried to interpolate and distinguish the concentration of heavy elements found in dust particles (Ismail-Zadeh-Hosseini et al., 2013). The resulting map is a qualitative division for various regions. These types of models are prepared periodically and seasonally. One of the most important environmental challenges that recently have been arisen in the Middle East and Iran is the dust phenomenon. This phenomenon has become one of the major problems in arid and semi-arid regions (Shamsipour and Safarrad, 2012). One of the factors affecting the severity of dust is the density factor and vegetation structure, which plays an essential role in controlling the occurrence of dust storms (Ta et al., 2004). Another important and effective factor in the occurrence of dust phenomena is geographical location and climatic conditions of the regions of the origin and areas affected by this phenomenon. The presence of Iran in the arid and semi-arid belt of the world and, on the other hand, the proximity to countries such as Arabia, Iraq and Syria, which have poor vegetation cover, low rainfall and high temperatures in most parts of these countries which are mostly the desert and are affected by desert conditions, air instability and wind flow is severe in these areas causing dust to happen in these regions. The intermittent drought in these regions has caused a periodic dust phenomenon in the western and southeastern parts of Iran. On the other hand, undesirable use of natural resources and environment by humans inside Iran and in the neighboring countries has exacerbated the dust phenomenon. This has been intensified in drought conditions and some other human activities, including land use change happening frequently in recent years, which have caused many environmental, health, social and economic problems and for politicians caused political problems and residents; dissatisfaction in these areas. Studies have shown that the dust phenomenon is a natural disaster that yearly causes many damages in the western and southwestern provinces in Iran. Consequently, familiarity with the creation process of this phenomenon can be effective in reducing the resulting damage (Omidvar, 2006). Since, numerous researchers have been conducted on fine dust particles such as (Engelstadler, 2001; Jalali and Davoudi, 2008), the western and southwest regions of Iran are among the regions with high incidence of this phenomenon and other studies such as (Pourali and Taghizadeh, 2011), have emphasized on the intensity of the fine dust particle phenomenon in southwest regions of the country in recent years. Although the use of new satellite imagery and detection methods of fine dust particles appear less in domestic research, they have been used extensively in foreign research such as (Rivera et al., 2006; Tsolmon et al., 2008). Acceptable results have also been achieved. In the researches carried out to monitor and identify the southwestern fine dust particles of the country, which have been carried out using remote sensing techniques and climatic methods and grading, the main source of the fine dust particles of this region is recognized outside of Iran especially in Iraq, Syria and Saudi Arabia (Ataie and Ahmadi, 2010).

\section{Conclusion}

The most important natural source of air pollution is dust in the majority of cities located in arid and semi-arid regions of Iran. But this kind of air pollution cannot be considered quite natural. Dust phenomenon is affected by several factors; human factors and natural factors that are divided into two types of constant factors over time and variables over time. Controlling human factors and monitoring natural variables over time can play an important role in controlling this phenomenon. The existence of spatial and temporal differences in the falling dust in different cities and in different months in the reports of Akbari in Behbahan city in Yazd and in Isfahan has indicated that in all of these reports, the amount of falling dust in the spring and winter has a spatial and temporal difference matching the results of dust sampling in Zahedan in the spring of 2015. According to the obtained results, it was found that the dust in spring of 2015 in Zahedan city has spatial and temporal changes. The spatial and temporal changes in dust can be caused due to the low green space, especially in the direction of wind blowing, developmental activities and 120-day winds of Sistan and the difference in urban density and urban marginal topographic complications. According to zoning map in the spring of 2015, the existence of an inconsistency in the dust spatial variations in the spring indicated that spring is the source of dust in the city. Since part of this amount is due to the drying of Hamoon Lake, wind erosion control measures in these areas can be effective in reducing the loss of dust in the city of Zahedan. In Iran, the use of geographical information systems and remote sensing to monitor natural hazards is increasing. Hence, the attention of managers of various fields of natural resources and environment to the capabilities of this software and attention to the researches have done in this regard sound necessary and useful. The results of many studies in the country showed that the frequency of dusty days is increasing. Therefore, very 
critical situations are coming and it is expected that the majority of urban and rural populations will migrate to the rest of the country, especially from western and southwestern regions leading the way to a lot of economic damage. Studies conducted in the country showed that the western regions of the country are more exposed to dust systems due to their geographical and climatic location and the proximity to the deserts of neighboring countries such as Iraq, Syria and Saudi Arabia, especially since most of the atmospheric system of the North West, West and Southwest are imported into the country. For this purpose, investigating, studying and recognizing physical and chemical composition of dust and soil resulting from it to determine and identify harmful elements and ultimately policy-making and planning for its elimination as regional alliances in the field of policy-making and foreign co-operation vital.

\section{Acknowledgment}

In the end, I must express my sincerest gratitude to all the colleagues and professors who co-operated in this research.

\section{Funding Information}

All the financial costs of this work, including sampling costs, sample analysis, publication of the work and etc were provided by the authors of the work.

\section{Author's Contributions}

All authors equally contributed in this work.

\section{Ethics}

In this article, all ethical principles related to scientificresearch articles such as validity and authenticity, originality, data collection in a standard manner, integrity, the accuracy of research and etc were observed.

\section{References}

Acosta, J. A., Faz, A., Martínez-Martínez, S., Zornoza, R., Carmona, D. M., \& Kabas, S. (2011). Multivariate statistical and GIS-based approach to evaluate heavy metals behavior in mine sites for future reclamation. Journal of Geochemical Exploration, 109(1-3), 8-17. https://doi.org/10.1016/j.gexplo.2011.01.004

Adomako, D., Nyarko, B. J. B., Dampare, S. B., SerforArmah, Y., Osae, S., Fianko, J. R., \& Akaho, E. H. K. (2008). Determination of toxic elements in waters and sediments from River Subin in the Ashanti Region of Ghana. Environmental Monitoring and Assessment, 141(1), 165-175. https://doi.org/10.1007/s10661-007-9885-X
Al-Khashman, O. A. (2007). The investigation of metal concentrations in street dust samples in Aqaba city, Jordan. Environmental geochemistry and health, 29(3), 197-207. https://doi.org/10.1007/s10653-0069065-x

Ataie, H., \& Ahmadi, F. (2010). Dusting as one of the environmental problems of the Islamic world (Case study: Khuzestan province). In International Congress of the Islamic World Geographers, (pp. 223), Zahedan, Sistan and Baluchestan University. http://www.ensani.ir/storage/Files/20101118114625 $-235 . p d f$

Azimzadeh, B., \& Khademi, H. (2013). Estimation of background concentration of selected heavy metals for pollution assessment of surface soils of Mazandaran province, Iran. Journal of Water Soil, 27: 548-559. https://www.sid.ir/en/journal/ViewPaper.aspx?id=35 9510

Azimzadeh, H. R., Montazer-Qaem, M., \& Torabi-Mirzai, F. (2010). Measurement of dust falling in Yazd city using the MDCO trap during the quarter of summer 2010. National Conference on Wind Erosion and Hurricanes, (pp. 1-6), Yazd University. https://www.civilica.com/Paper-ISADMC02ISADMC02_012

Bini, C., Sartori, G., Wahsha, M., \& Fontana, S. (2011). Background levels of trace elements and soil geochemistry at regional level in NE Italy. Journal of Geochemical Exploration, 109(1-3), 125-133. https://doi.org/10.1016/j.gexplo.2010.07.008

Cai, L., Xu, Z., Ren, M., Guo, Q., Hu, X., Hu, G., ... \& Peng, P. (2012). Source identification of eight hazardous heavy metals in agricultural soils of Huizhou, Guangdong Province, China. Ecotoxicology and environmental safety, 78, 2-8. https://doi.org/10.1016/j.ecoenv.2011.07.004

Chabukdhara, M., \& Nema, A. K. (2012). Assessment of heavy metal contamination in Hindon River sediments: a chemometric and geochemical approach. Chemosphere, 87(8), 945-953. https://doi.org/10.1016/j.chemosphere.2012.01.055

Chaoyang, W. E. I., Cheng, W. A. N. G., \& Linsheng, Y. A. N. G. (2009). Characterizing spatial distribution and sources of heavy metals in the soils from miningsmelting activities in Shuikoushan, Hunan Province, China. Journal of Environmental Sciences, 21(9), 1230-1236. https://doi.org/10.1016/S10010742(08)62409-2

Chen, T., Liu, X., Li, X., Zhao, K., Zhang, J., Xu, J., ... \& Dahlgren, R. A. (2009). Heavy metal sources identification and sampling uncertainty analysis in a field-scale vegetable soil of Hangzhou, China. Environmental Pollution, 157(3), 1003-1010. https://doi.org/10.1016/j.envpol.2008.10.011 
Chung, Y. S., Kim, H. S., Jugder, D., Natsagdorj, L., \& Chen, S. J. (2003). On sand and duststorms and associated significant dustfall observed in ChongjuChongwon, Korea during 1997-2000. Water, Air and Soil Pollution: Focus, 3(2), 5-19. https://doi.org/10.1023/A:1023242000367

Darvish-Sefat, A. A., Pir bavaghar, M., Rajab Pour Rahmati, M., Ostovari, A. R., \& Aronof, A. (2013). Remote Sensing for GIS Managers. Tehran: Tehran University Press, ISBN-13: 978-964-03-6295-2.

Davis, H. T., Aelion, C. M., McDermott, S., \& Lawson, A. B. (2009). Identifying natural and anthropogenic sources of metals in urban and rural soils using GISbased data, PCA and spatial interpolation. Environmental Pollution, 157(8-9), 2378-2385. https://doi.org/10.1016/j.envpol.2009.03.021

Ekhtesasi, M. R., Ahmadi, H., Khalili, A., Saremi-Naini, M. A., \& Rajabi, M. R., (2006). Application of mud, mudflow and sandy mud in wind erosion analysis and directional direction determination Smooth sand (Case study: Yazd-Ardakan plain). Journal of Natural Resources Faculty, 59, 533-541. http://www.sid.ir/fa/journal/ViewPaper.aspx?id=82237

Engelstadler, S. (2001). Dust storm frequencies and their relationships to land surface conditions. FreidrichSchiller University Press, Jena, Germany.

Eze, P. N., Udeigwe, T. K., \& Stietiya, M. H. (2010). Distribution and potential source evaluation of heavy metals in prominent soils of Accra Plains, Ghana. Geoderma, 156(3-4), 357-362. https://doi.org/10.1016/j.geoderma.2010.02.032

Fallah-Zozooly, M., Vafaie-Nezhjad, A., KheyrkhahZarkesh, M. M., \& Ahmadi-Dehkaa, F. (2014). Synoptic monitoring and analysis of dust by remote sensing and GIS (Case Study: June 18, 2012). Journal of Geographic Information, 23, 69-80. https://www.civilica.com/Paper-JR_SEPEHRJR_SEPEHR-23-91_005.html

Feng, J. L., Zhu, L. P., Ju, J. T., Zhou, L. P., Zhen, X. L., Zhang, W., \& Gao, S. P. (2008). Heavy dust fall in Beijing, on April 16-17, 2006: Geochemical properties and indications of the dust provenance. Geochemical Journal, 42(2), 221-236. https://doi.org/10.2343/geochemj.42.221

Frechen, M., \& Dodonov, A. E. (1998). Loess chronology of the Middle and Upper Pleistocene in Tadjikistan. Geologische Rundschau, 87(1), 2-20. https://doi.org/10.1007/s005310050185

Goossens, D., \& Rajot, J. L. (2008). Techniques to measure the dry aeolian deposition of dust in arid and semi-arid landscapes: a comparative study in West Niger. Earth Surface Processes and Landforms: The Journal of the British Geomorphological Research Group, 33(2), 178-195. https://doi.org/10.1002/esp.1533
Goudie, A. S. (2009). Dust storms: Recent developments. Journal of environmental management, 90(1), 89-94. https://doi.org/10.1016/j.jenvman.2008.07.007

Gu, Y. G., Wang, Z. H., Lu, S. H., Jiang, S. J., Mu, D. H., \& Shu, Y. H. (2012). Multivariate statistical and GIS-based approach to identify source of anthropogenic impacts on metallic elements in sediments from the mid Guangdong coasts, China. Environmental pollution, 163, 248-255. https://doi.org/10.1016/j.envpol.2011.12.041

Guo, G., Wu, F., Xie, F., \& Zhang, R. (2012). Spatial distribution and pollution assessment of heavy metals in urban soils from southwest China. Journal of Environmental Sciences, 24(3), 410-418. https://doi.org/10.1016/S1001-0742(11)60762-6

Hai, C. X., Yuan, C. S., Liu, G. T., Li, X. J., Zhang, F., \& Zhang, X. J. (2008). Research on the components of dust fall in Hohhot in comparison with surface soil components in different lands of Inner Mongolia Plateau. Water, air and soil pollution, 190(1), 27-34. https://doi.org/10.1007/s11270-007-9576-9

Hamzeh, M. H., Mirzaie, M., \& Mozaffari, H. (2009). Concentrations of $\mathrm{Pb}, \mathrm{Zn}, \mathrm{Cu}$ and $\mathrm{Cd}$ and their distribution in the urban environment of Kerman, Iran. Journal of Environmental Science and Technology, 11, 161-177. http://jest.srbiau.ac.ir/article_240_31.html

Holden, T. (2006). Technical fact sheet: Air qualitydust monitoring. Environmental Defender's Office Ltd

(NSW). www.australiancoalalliance.com/Information/air_qu ality_dust060405.pdf

Indoitu, R., Orlovsky, L., \& Orlovsky, N. (2012). Dust storms in Central Asia: Spatial and temporal variations. Journal of Arid Environments, 85, 62-70. https://doi.org/10.1016/j.jaridenv.2012.03.018

Iranmanesh, F., Khedri, A., \& Akram, M. (2005). Investigating dust extraction regions and their distribution characteristics in the storms of Sistan region using satellite imagery processing. J. Res. Dev. Nat. Resources, 18: 25-33. https://elmnet.ir/Article/1151734-31632

Ismail-Zadeh-Hosseini, M., Azimi-Zadeh, H. R., IslamiKalantari, M., Ekhtesasi, M. R., \& Sodaie-Zadeh, H. (2013). Investigating the lead density in the dust falling of Yazd City. Proceedings of the 3rd National Conference Erosion and Wind Turbines, (pp. 1-7), Yazd, Yazd University. https://www.civilica.com/Paper-ISADMC03ISADMC03_109

Jalali, N., \& Davoudi, M. H. (2008). Inspecting the originsand causes of the dust storms in the Southwest andWest parts of Iran and the regions affected. Internal reports of Soil Conservation and Watershed anagement Research Institute (SCWMRI), Iran. 
Khosravi, M. (2010). Vertical distribution of storm dust in the Middle East using NAAPS model Case: SistanIran. In International Congress of Geographers of the Islamic World, Zahedan. https://www.civilica.com/Paper-ICIWG04ICIWG04_053.html

Kimura, R., Bai, L., \& Wang, J. (2009). Relationships among redust outbreaks, vegetation cover and surface soil water content on the Loess Plateau of China, 1999-2000. Catena, 77(3), 292-296. https://doi.org/10.1016/j.catena.2009.02.016

Krinner, G., Boucher, O., \& Balkanski, Y. (2006). Ice-free glacial northern Asia due to dust deposition on snow. Climate Dynamics, 27(6), 613-625. https://doi.org/10.1007/s00382-006-0159-z

Lashkari, H., \& Keykhosravi, G. (2008). Statistical synoptic analysis of dust storm in khorasan razavi province (1993-2005). Physical Geography Research Quarterly, 65, 17-33. http://www.sid.ir/En/Journal/ViewPaper.aspx?ID=1 38001

Li, X., \& Feng, L. (2012). Geostatistical analyses and fractionation of heavy metals in urban soil from industrial district in Weinan, NW China. Environmental Earth Sciences, 67(7), 2129-2140. https://doi.org/10.1007/s12665-012-1653-8

Li, X., Ge, L., Dong, Y., \& Chang, H. C. (2010, July). Estimating the greatest dust storm in eastern Australia with MODIS satellite images. In 2010 IEEE International Geoscience and Remote Sensing Symposium (pp. 1039-1042). IEEE. https://doi.org/10.1109/IGARSS.2010.5649212

Lin, Y. P., Cheng, B. Y., Shyu, G. S., \& Chang, T. K. (2010). Combining a finite mixture distribution model with indicator kriging to delineate and map the spatial patterns of soil heavy metal pollution in Chunghua County, central Taiwan. Environmental Pollution, 158(1), 235-244 https://doi.org/10.1016/j.envpol.2009.07.015

Loska, K., Wiechuła, D., \& Korus, I. (2004). Metal contamination of farming soils affected by industry. Environment international, 30(2), 159-165. https://doi.org/10.1016/S0160-4120(03)00157-0

Lu, A., Wang, J., Qin, X., Wang, K., Han, P., \& Zhang, S. (2012). Multivariate and geostatistical analyses of the spatial distribution and origin of heavy metals in the agricultural soils in Shunyi, Beijing, China. Science of the total environment, 425, 66-74. https://doi.org/10.1016/j.scitotenv.2012.03.003

Lu, X., Wang, L., Li, L. Y., Lei, K., Huang, L., \& Kang, D. (2010). Multivariate statistical analysis of heavy metals in street dust of Baoji, NW China. Journal of hazardous materials, 173(1-3), 744-749. https://doi.org/10.1016/j.jhazmat.2009.09.001
Mehrshahi, D., \& Nekounam, Z. (2009). Statistical analysis of dust and dust wind patterns in Sabzevar city. Journal of Geography, 7, 83-104. www.ensani.ir/storage/Files/20120326120631-115577.pdf

Mei, D., Xiushan, L., Lin, S., \& Ping, W. A. N. G. (2008). A dust-storm process dynamic monitoring with multitemporal MODIS data. The International Archives of the Photogrammetry, Remote Sensing and Spatial Information Sciences, $37 . \quad 965-969$. https://pdfs.semanticscholar.org/34b1/5b45c20c6f07c d000645beb2ed66c3e8ddc0.pdf

Micó, C., Recatalá, L., Peris, M., \& Sánchez, J. (2006). Assessing heavy metal sources in agricultural soils of an European Mediterranean area by multivariate analysis. Chemosphere, 65(5), 863-872. https://doi.org/10.1016/j.bbr.2011.03.031

Miller, S. D. (2003). A consolidated technique for enhancing desert dust storms with MODIS. Geophysical Research Letters, 30(20), 2071-2074. https://doi.org/10.1029/2003GL018279

Muller, G. (1969). Index of geoaccumulation in sediments of the Rhine River. Geojournal, 2, 108-118. https://ci.nii.ac.jp/naid/10030367619/

Nadafi, K. (2009). Dust and air pollution with an emphasis on health and environmental effects of, Environmental Health Congress. https://www.civilica.com/PaperNCEH12-NCEH12_277

Namazi, N., Salehi, M. H., \& Mohammadi, J. (2015). Spatial and temporal variability of some of heavy metals in aerosols of Lenjanat region, Esfahan. Journal of Water and Soil, 29, 114-125. https://jsw.um.ac.ir/index.php/jsw/article/view/25786

Negin, T., Nazem-Sadat, M. J., \& Abtahi, A. (2013). Check dust monitoring using remote sensing and GIS in the Khuzestan province. In 3rd National Conference on Wind Erosion and Dust Storms, (pp. 1-7), Scientific Society for Management and Control of Desert Regions of Iran. https://www.civilica.com/Paper-ISADMC03 ISADMC03_080.html

Nimrozi, A., \& Moaf-Pourian, G. A. (2012). Investigation of heavy metals dispersion in the Soil of Shiraz-AbBaric. Thirty-first Earth Science Forum. https://www.civilica.com/Paper-GSI31-GSI31_151

Omidvar, K. (2006). Synoptic study and analysis of storms in Yazd and Ardakan plains. Journal of Geographic Research, 21, 43-43. https://library.tebyan.net/fa/Viewer/Pdf/109674/1

Omidvar, K., \& Nekounam, Z. (2009). The application of wind mud and mud in the analysis of the dust phenomenon and the determination of the seasonal winds with this phenomenon (Sabzevar County). National Geography Research, 43, 85-104. https://journals.ut.ac.ir/article_23072.html 
Pourali, M., \& Taghizadeh, A. (2011). Investigating the causes and sources of dust in Khuzestan province. Growth Geography Education, 25, 8-13. https://www.noormags.ir/

Prospero, J. M., Ginoux, P., Torres, O., Nicholson, S. E., \& Gill, T. E. (2002). Environmental characterization of global sources of atmospheric soil dust identified with the Nimbus 7 Total Ozone Mapping Spectrometer (TOMS) absorbing aerosol product. Reviews of Geophysics, 40(1), 2-1. https://doi.org/10.1029/2000RG000095

Qishlaqi, A., Moore, F., \& Forghani, G. (2009). Characterization of metal pollution in soils under two landuse patterns in the Angouran region, NW Iran; a study based on multivariate data analysis. Journal of Hazardous Materials, 172(1), 374-384. https://doi.org/10.1016/j.jhazmat.2009.07.024

Rasouli, A. A., Sari-Sarraf, B., \& Mohammadi, G. H. (2010). Dust climatology trends in the west of the country in the last 55 years using nonparametric statistical methods. Journal of National Geography, 3 , $15-28$ http://www.sid.ir/fa/journal/ViewPaper.aspx?id=123 358

Reilly, C. (2008). Metal Contamination of Food: Its Significance for Food Quality and Human Health. Oxford, UK: Wiley-Blackwell, ISBN-10: 0470995092.

Rezaie-Moghaddam, M. H., \& Mahdian-Boroujeni, M. (2015). Explanation of the microspheres using AVHRR satellite images of NOAA satellite (Case study: Southwest of Iran). Journal of Geography Environmant Sustainability, 5, 1-13. http://ges.razi.ac.ir/article_490.html

Ridgwell, A.J., 2003. Implications of the glacial $\mathrm{CO}_{2}$ "iron hypothesis" for Quaternary climate change. Geochemistry Geophysics Geosystems, 4, 1-10. https://doi.org/10.1029/2003GC000563

Rivera, N. I., Bleiweiss, M. P., Hand, J. L., \& Gill, T. E. (2006). Characterization of dust storms sources in southwestern U. S and Northwestern Mexico using remote sensing imagery. In 14th Conference on Satellite Meteorology and Oceanography, (pp. 1-29), American Meteorological Society, Atlanta. https://opensky.ucar.edu/islandora/object/manuscripts

Rodríguez, I., Galí, S., \& Marcos, C. (2009). Atmospheric inorganic aerosol of a non-industrial city in the centre of an industrial region of the North of Spain and its possible influence on the climate on a regional scale. Environmental Geology, 56(8), 1551-1561. https://doi.org/10.1007/s00254-008-1253-9

Roskovensky, J. K., \& Liou, K. N. (2005). Differentiating airborne dust from cirrus clouds using MODIS data. Geophysical Research Letters, 32(12), L12809-L12809. https://doi.org/10.1029/2005GL022798
Rossini, P., Matteucci, G., \& Guerzoni, S. (2010). Atmospheric fall-out of metals around the Murano glass-making district (Venice, Italy). Environmental Science and Pollution Research, 17(1), 40-48. https://doi.org/10.1007/s11356-009-0122-8

Schlesinger, P., Mamane, Y., \& Grishkan, I. (2006). Transport of microorganisms to Israel during Saharan dust events. Aerobiologia, 22(4), 259. https://doi.org/10.1007/s10453-006-9038-7

Shamsipour, A. A., \& Safarrad, T. (2012). Satellite analysis-synthesis of the dust (July 2009). Journal of National Geography Research, 79, 111-126. www.sid.ir/fa/journal/ViewPaper.aspx?id=160728

Sharma, R. K., Agrawal, M., \& Marshall, F. M. (2008). Atmospheric deposition of heavy metals $(\mathrm{Cu}, \mathrm{Zn}, \mathrm{Cd}$ and $\mathrm{Pb}$ ) in Varanasi city, India. Environmental Monitoring and Assessment, 142(1), 269-278. https://doi.org/10.1007/s10661-007-9924-7

Shayestefar, M. R., \& Rezaei, A. (2011). Evaluation of Contamination Rate and Heavy Metals Distribution in the Sediments of Sarcheshmeh Copper Mine Using Geochemical Data and Statistical Studies. Iranian Journal of Mining Engineering, 6(11), 25-34. http://ijme.iranjournals.ir/article_1513.html

Sow, M., Goossens, D., \& Rajot, J. L. (2006). Calibration of the MDCO dust collector and of four versions of the inverted frisbee dust deposition sampler. Geomorphology, 82(3-4), 360-375. https://doi.org/10.1016/j.geomorph.2006.05.013

Su, Y. Z., \& Yang, R. (2008). Background concentrations of elements in surface soils and their changes as affected by agriculture use in the desert-oasis ecotone in the middle of Heihe River Basin, North-west China. Journal of Geochemical Exploration, 98(3), 57-64. https://doi.org/10.1016/j.gexplo.2007.12.001

Ta, W. H., Xiao, J., Xiao, G., Yang, T., \& Zhang, X. (2004). Measurements of dust deposition in Ganus Province, China. Geomorphology, 57, 41-51. https://doi.org/10.1016/S0169-555X(03)00082-5

Tabatabaie, T., Karbasi, A., Moattar, F., \& Monavari, S. M. (2013). Application of multivariate analysis of predicted particles (case study: Bushehr). Journal of RS and GIS for National Resources, 5, 35-46. http://girs.iaubushehr.ac.ir

Tamsaki, A., Khorani, A., Dervishi-Blurani, A., \& Nohegar, A. (2016). Monitoring and anticipation of dust storms using data from dwarves, spatial information system and terrestrial data based on the study of climate change and vegetation changes (Case Study: South and South East of Iran). Journal of Remote Sensing and GIS Iran, 7, 27-44. http://gisj.sbu.ac.ir/article/view/14202 
Toy, T. J., Foster, G. R., \& Renard, K. G. (2002). Soil Erosion: Processes, Prediction, Measurement and Control. New York: John Wiley and Sons, ISBN-10: 0471383694.

Tsolmon, R., Ochirkhuyag, L., \& Sternberg, T. (2008). Monitoring the source of trans-national dust storms in north east Asia. International Journal of Digital Earth, 1(1),

119-129. https://doi.org/10.1080/17538940701782593

Wu, S., Zhou, S., Li, X., Jackson, T., \& Zhu, Q. (2011). An approach to partition the anthropogenic and natural components of heavy metal accumulations in roadside agricultural soil. Environmental Monitoring and Assessment, 173(1), 871-881. https://doi.org/10.1007/s10661-010-1430-7

Xia, X., Chen, X., Liu, R., \& Liu, H. (2011). Heavy metals in urban soils with various types of land use in Beijing, China. Journal of Hazardous Materials, 186(2-3), 2043-2050. https://doi.org/10.1016/j.jhazmat.2010.12.104

Yahaya, M. I., Ezeh, G. C., Musa, Y. F., \& Mohammad, S. Y. (2010). Analysis of heavy metals concentration in road sides soil in Yauri, Nigeria. African Journal of Pure and Applied Chemistry, 4(3), 022-030. www.academicjournals.org/article/article137949624 8_Yahaya\%20et\%20al.pdf

Yang, X., Zhu, B., Wang, X., Li, C., Zhou, Z., Chen, J., .. \& Lu, Y. (2008). Late Quaternary environmental changes and organic carbon density in the Hunshandake Sandy Land, eastern Inner Mongolia, China. Global and Planetary Change, 61(1-2), 70-78. https://doi.org/10.1016/j.gloplacha.2007.08.007
Yang, Z., Lu, W., Long, Y., Bao, X., \& Yang, Q. (2011). Assessment of heavy metals contamination in urban topsoil from Changchun City, China. Journal of Geochemical Exploration, 108(1), 27-38. https://doi.org/10.1016/j.gexplo.2010.09.006

Zarasvandi, A., Carranza, E. J. M., Moore, F., \& Rastmanesh, F. (2011). Spatio-temporal occurrences and mineralogical-geochemical characteristics of airborne dusts in Khuzestan Province (southwestern Iran). Journal of Geochemical Exploration, 111(3), 138-151. https://doi.org/10.1016/j.gexplo.2011.04.004

Zhang, C., Wu, L., Luo, Y., Zhang, H., \& Christie, P. (2008). Identifying sources of soil inorganic pollutants on a regional scale using a multivariate statistical approach: role of pollutant migration and soil physicochemical properties. Environmental Pollution, 151(3), 470-476. https://doi.org/10.1016/j.envpol.2007.04.017

Zolfaghari, H., \& Abedzadeh, H. (2005). Synoptic analysis of dust systems in the West of Iran. Journal of Geography and Development (Iran), 6, 173-188. http://www.sid.ir/fa/journal/ViewPaper.aspx?id=52338

Zoljoodi, M., Didevarasl, A., \& Saadatabadi, A. R. (2013). Dust events in the western parts of Iran and the relationship with drought expansion over the dust-source areas in Iraq and Syria. Atmospheric and Climate Sciences, 3, 321-336. https://doi.org/10.4236/acs.2013.33034 